\title{
MALC's Second Decade: Commitment to Communication
}

\begin{abstract}
Among the pedantic plethora of professional programs that often seem to strangle rather than stimulate the academic librarian, the Midwest Academic Librarians Conference (MALC) has gained a reputation for stimulating, substantive programs in an informal yet attractive setting and an absence of the usual formalized structure. This brief summary of a decade of conferences is intended to supplement an earlier article by the author.
\end{abstract}

$\mathrm{V}$ ED EFFORTS of academic librarians, have been largely responsible for the continuing vitality of the Midwest Academic Librarians Conference, a nonorganization that celebrates its twentieth anniversary in May $1975 . .^{1}$ For a group which has no structured organization, no elected officers, and no dues, this in itself is something of an accomplishment in a profession surfeited with organizations, committees, and conferences. "The proliferation of professional groups within the library world has been a longstanding concern of many individuals, and the value of many existing units affiliated with state and national associations has frequently been questioned."2 This statement, written a decade ago, is still basically true as professional librarians continue to seek their identity.

More than twenty years ago, there were academic librarians who sensed that existing national and state library organizations were not sufficient, especially for those professionals who were not top administrators and who seldom

H. Vail Deale is director of libraries, Beloit College, Beloit, Wisconsin. had contact with colleagues in other institutions pursuing similar work. A need was felt for some kind of nonstructured, informal communication among academic librarians that would provide an exchange of ideas on a more practical level. As Russell S. Dozer, former librarian at DePauw University, once wrote:

MALC was established, as I understand it, to be a vital force outside these established organizations, and to be free of their rigid administrative, constitutional, and other controls. In other words . . . a grass-roots group, free to discuss, free to explore, without resorting to precedents, etc. ${ }^{3}$

Over one hundred academic librarians traveled to East Lansing for the first conference in May 1956; between four and five hundred librarians from a dozen midwestern states and the District of Columbia are expected to attend the twentieth anniversary MALC sessions, May 23-24, 1975, at Ohio State University, Columbus. The purpose of this paper is to summarize MALC's second decade. Materials for this research have come largely from MALC archives though the author has participated in all but two conferences. 
The tenth anniversary conference held at Beloit, April 30-May 1, 1965, had as its theme: "Academic Library Cooperation in Mid-America." It drew upon the rich professional resources of America's heartland for its major speakers and for panelists in the various discussion groups. Host for the two-day conference in southern Wisconsin was H. Vail Deale, director of libraries at Beloit, assisted by James F. Holly (then librarian, Macalester College, Minneapolis), chairman of the MALC Steering Committee.

Gordon Williams, director of the Midwest Interlibrary Center, Chicago (now the Center for Research Libraries), spoke at the anniversary banquet Friday evening on "Academic Librarianship: The State of the Art." A panel session that afternoon considered "Academic Library Cooperation in MidAmerica," and included Katharine M. Stokes (Western Michigan), Eugene B. Jackson (IBM), Richard D. Walker (Library School, University of Wisconsin-Madison), Robert Golter (Wheaton College), Barton R. Burkhalter, and Clover M. Flanders (both from the University of Michigan). Two discussion periods on Saturday gave participants a choice between "Automation and the Academic Library" and "Educational Resources Centers." Mark Gormley (then librarian, University of Wisconsin-Milwaukee) addressed the closing luncheon session on the topic: "Rapid Expansion: Building a Teachers College Collection into a University Library," using his own institution as a case study.

The anniversary conference followed guidelines as originally conceived: It was held on a small college campus, with a recently completed building, and provided ample opportunity for the friendly and informal exchange of ideas among the participants. A crosssection of academic librarians from nearly a dozen midwestern states at- tended. Friday morning and Saturday afternoon were especially designated for guided tours of the Colonel Robert H. Morse Library, and for those who wished more specific information concerning the building and its operations. The conference closed with Saturday's luncheon and a brief business session, at which time Carl H. Sachtleben (then librarian, Valparaiso University) was introduced as incoming chairman of MALC's Steering Committee.

\section{CONFERENCES INVOLVE Planning Ahead}

In the twenty-year history of MALC, perhaps no conference created more planning headaches than the one held in the spring of 1966 . Nearly every academic librarian in the state of Ohio, at one time or another, was involved in the preliminary planning. Originally it was to have been jointly sponsored by Denison and Antioch, but the final decision was to hold MALC's eleventh conference at Wittenberg University the weekend of May 13-14, 1966. Robert L. Mowery was the host librarian; Carl Sachtleben, chairman of the MALC Steering Committee. Sessions were held in Weaver Chapel, architecturally combined with the new Wittenberg Library. The opening program on "Special Collections in the College Library" was shared by panel members Edward Heintz (Kenyon) on archives; Jean Archibald (Macalester) on rare books; Bruce Thomas (Antioch) on "core" collections; Evan Farber (Earlham) on non-Western collections; and John Reed (Ohio Wesleyan) on denominational history collection. Ben Lewis, librarian of Denison University, moderated the session, and participants divided into small discussion groups following the panel talks. Myrl Ricking, who at the time was director of the Office of Personnel (ALA), was speaker at the Friday night dinner discussing current problems in recruitment. 
Saturday morning's schedule provided time for tours of neighboring academic libraries, browsing on the Wittenberg campus, and informal conversation. Harry Skallerup (then head cataloger, University of Iowa) was the luncheon speaker, with the subject: "The Use of the Library of Congress Classification and its Application in Academic Institutions." The topic was timely, since many libraries were considering a change-over from Dewey to LC classification.

At the instigation of Frazer Poole, then director of the Chicago Circle Library of the University of Illinois, MALC was invited to hold its twelfth annual conference in the excitingly designed buildings of Illinois' Chicago campus. Dates of the conference were May 5-6, 1967. The entire morning of the first day was set aside for "tours of the campus, the library, and the bookstore," and participants were on their own for lunch in one of the three cafeterias in the Chicago Circle Center. Kenneth Soderland (assistant director, University of Chicago Library) presided at the opening session. Robert F. Asleson, general manager, University Microfilms, spoke on "The Future Inter-Relationships between Photocopying Industry and College and University Libraries." Commentators on his talk were Richard Chapin (director of libraries, Michigan State) and William Budington (librarian of the John Crerar Library, Chicago).

Walter Netsch, major architect of the Chicago Circle campus, from the firm of Skidmore, Owings and Merrill, was speaker at the Friday evening dinner in the Illinois Room, Chicago Circle Center. Prior to his address on "Transition in Library Design Since World War II and its Implications for the Future," delegates were welcomed by Chancellor Norman Parker and host librarian Frazer Poole.

Saturday morning's session was devoted to the MARC project of the Library of Congress, with Allen Hogden (Chicago Circle Library) presiding. He introduced the speakers, Henriette Avram (Library of Congress) and the librarian at Argonne National Laboratory, Hillis Griffin. Participants were given an opportunity for questions and answers on the MARC project. At the closing luncheon, presided over by MALC chairman, Carl Sachtleben, a summary of conference talks was given by Frazer Poole.

Although the twelfth meeting of MALC met in a new library facility, and although it provided an opportunity for Chicago area librarians to participate, in my opinion it did not seem to have the esprit de corps or relaxed atmosphere provided by other MALC conferences. Many librarians have felt that if we are to avoid mere imitation and duplication of other professional gatherings, MALC should hold to its original guidelines. Such comments are in no sense meant to deprecate the hard work and hospitality of the Chicago Circle Library staff, nor to seem unappreciative of the conference planning, but rather to capture the spoken and unspoken feelings of those who would like to maintain the professional intimacy and friendly informality that has made the Midwest Academic Librarians Conference somewhat unique.

\section{Minnesota: Three For the Price of ONE}

The brochure announcing the thirteenth MALC conference at Winona, Minnesota, May 3-4, 1968, boasted, "Three new libraries in one town! Progressive Cooperative Project! Beautiful scenery! Good transportation!" The three cosponsoring institutions were the College of St. Teresa, St. Mary's College, and Winona State College; Mrs. John Williams was the general chairman, and host librarians were Sister M. Eone (St. Teresa), Jean Brose (St. Mary's), and Edward T. Jacobsen (Wi- 
nona State). It was a well-conceived and well-planned conference which lived up to its advance publicity, including the provision for good weather to enjoy the beautiful scenery.

"Automation in the Small College Library" was discussed by a panel at the Friday afternoon opening session held in Somson Auditorium of the Winona State College. Edward Jacobsen moderated the program, consisting of Justin Kniemeyer and J. Van der Veer Judd (both of St. Mary's). Lourdes Hall of the College of St. Teresa was the scene of Friday evening's dinner; the speaker was Julian Plante, curator of the Monastic Manuscript Library (St. John's University). Tours of the College of St. Teresa Library followed the dinner.

Conference delegates divided into six discussion groups Saturday morning when they convened in the Fitzgerald Library at St. Mary's College. The topics included: library statistics, classification change-over, the library-college concept, curriculum libraries, North Central Association visitations, and equipment grants. The final conference session, presided over by MALC chairman, Maurice W. Boatman (then assistant librarian, Grinnell), followed the Saturday noon luncheon at St. Mary's College.

\section{Two Groups Share Miami CONFERENCE}

The beautiful campus of Miami University (Oxford, Ohio) was the site for the fourteenth MALC conference the weekend of May 2-3, 1969. Meeting at the same time, according to the advance brochure, was the Ohio Valley Group Technical Services Librarians. Spectacular weather combined with an early spring, enhanced the tours of the Miami campus and the nearby academic libraries included as part of the Saturday morning program: Earlham at Richmond (Ind.), Xavier at Cincinnati, and Miami University's Middletown and
Hamilton campuses. One of the best attended sessions was the discussion Saturday sponsored by the Ohio Valley Group on "Mating MARC II with OCLC" which attracted over 300 librarians. Curtis E. Higgins, senior programmer and systems analyst of the Ohio College Library Center, was the main speaker; panelists included, Betty Wasson (Western College for Women), Leo Rift (then at Bowling Green State), and Harold Apel (Marshall University, Huntington, West Virginia).

"Librarians' Relations With Students" was the subject of a Friday afternoon panel that included: Howard W. Cordell (then at Cornell College); H. Vail Deale (Beloit); and Stuart Forth (then at the University of Kentucky). The banquet speaker Friday evening was $\mathrm{Pa}$ tricia B. Knapp of Wayne State University's Library School, who addressed herself to "Rationalizing Library Service to Undergraduate Students." Saturday's final session followed luncheon in the Heritage Room of the spacious Student Center. MALC chairman Maurice Boatman presided and introduced his successor, William C. Roselle (University of Wisconsin-Milwaukee). Though the hospitality and weather were warm and generous, the programming at Miami left something to be desired. Discussion groups Friday afternoon, an after-dinner speech, and tours on Saturday morning, did not seem "solid fare" for those who had given up a weekend for professional stimulation. Some participants were able to share in the Ohio Valley Group program, but for others the menu seemed on the light side. It raises the question of how successful can programs be when two groups meet at the same time in the same place.

\section{"Cooperation"-Every Five Years?}

George Rausch, director of libraries, Drake University, and Barbara Bell, librarian, Grandview College, jointly 
hosted the fifteenth MALC conference held in Des Moines, May 8-9, 1970. The theme of the conference, "New Ventures in Academic Library Cooperation," appeared to be a follow-up on the theme of the tenth anniversary conference at Beloit five years earlier. After a welcoming luncheon on the Drake campus Friday noon, William Roselle, MALC chairman, opened the first general session, introducing Richard $\mathrm{M}$. Dougherty (then associate director of libraries, University of Colorado). He spoke on the subject: "Library Cooperation: Promises or Pratfalls."

The grand ballroom of the Hotel Savery was the scene for the cocktail hour and banquet on Friday evening. Willard L. Boyd, president of the University of Iowa, who was scheduled to be the speaker, sent last minute regrets due to problems with "student unrest" on his home campus. However, his provocative address, "Our Mutual Problems," was read by Leslie Dunlap, director of libraries, University of Iowa. Saturday morning sessions, held on the Grandview College campus, were preceded by a delightful coffee klatch. Participants had six options in the discussion groups: cooperation between state universities in Ohio; coordination of automated library services at state universities in Iowa; North East Iowa academic libraries; the micrographic cata$\log$ retrieval systems of the Information Dynamics Corporation; the Associated Colleges of the Midwest Periodical Bank; and a statewide interlibrary loan network.

Barbara L. Bell, Grandview Librarian, presided at the closing session following luncheon. Ample time was provided for tours of both Drake and Grandview libraries.

\section{INDIANA: "RARE" But Well Done}

The outstanding attraction for those attending the sixteenth MALC confer- ence in Bloomington, Indiana, May 2122,1971 , was the opportunity to see the new Lilly Rare Book Library at Indiana University. Following the pattern of former conferences, Friday morning was set aside for tours of the Lilly Library and the various branch collections of the Indiana University Libraries. Participants were on their own for luncheon, and the opening general session convened in Whittenberger Auditorium of the Student Union. William Roselle, MALC chairman, presided and introduced Stuart Forth (University of Kentucky), who spoke on "Faculty Status for Librarians in the Seventies" to an audience of several hundred librarians.

An informal reception was held in a downtown motor hotel prior to the evening banquet in the Student Union on campus. Jane G. Flener, assistant director of libraries, presiding at the banquet, introduced the speaker: Jessie Carney Smith (university librarian, Fiske University). Her topic was: "The Impact of Black Studies Programs on the Academic Library." Six topics relating to the Indiana University Libraries involved the discussion groups Saturday morning. Robert A. Miller, Indiana's director of libraries, led the group interested in "The Indiana University Library Building"; Molete Morelock and Mary B. Baker discussed "The Indiana Libraries Network"; "New Programs in Teaching the Use of College Libraries" was presented by Charlotte Millis (Wabash College); Cecil K. Byrd (Indiana) led the group on "Subject Specialists in the Indiana University Libraries"; Dominique Rene de Lerma, director of the Black Music Center, talked about the center's program; and microforms was the all-inclusive topic considered by a panel made up of W. H. Baatz (Indiana), Theodore F. Welch (Northwestern), Steven Rice (vice-president, University Microfilms), and Rodney Wright, an intern at Indiana. 
A brief final session was held prior to the noon hour, allowing participants to make their own arrangements for luncheon and the afternoon. Because of its location in southern Indiana, librarians from Kentucky and Tennessee also attended the conference, in addition to those from the regular core of midwestern states. In spite of the size of the institution and its location, the hospitality of the Indiana University Libraries staff and the program planners provided a stimulating weekend.

\section{New Scenes ... \\ NEW FACES . . .}

Each succeeding year newcomers discover the Midwest Academic Librarians Conference. There were some sixty new faces at the seventeenth MALC meeting in the Orrington Hotel, Evanston (Ill.), the weekend of May 18-20, 1972. Jointly sponsored by the Northwestern University Library and the Regenstein Library of the University of Chicago, most sessions were held in Evanston. Thursday, May 18, was used as a day of travel, with participants arriving in the late afternoon and throughout the evening. Tours of the strikingly designed library at Northwestern were available for the early arrivals and throughout the conference. The theme of the seventeenth conference was "Momentum for Academic Library Change," and five different topics were considered in the Friday discussion groups. "Copyright Law” was led by William Moritz, Thomas Brennan, William North, Edmon Low, and Theodore Giese; "MINITEX" (Minnesota's statewide interlibrary loan system) was discussed by its able director, Alice Wilcox, Father Anthony Lachner, Edward Jacobsen, and Ralph Hopp; "The Periodical Bank of the Associated Colleges of the Midwest" was presented by Irma M. Lucht (its director), Richard Press, Frederick Jackson, Everett Howell, and Gordon Williams; Northwestern's new building was in the hands of university librarian, John P. McGowan; and "Automation at Northwestern" was the subject of a panel that included Karen Horny, Velma Veneziano, James Agaard, Rolf Erickson, Elizabeth J. Furlong, and Susan Spector.

Walter A. Netsch, design partner of Skidmore, Owings and Merrill, Chicago architects, was the speaker for the Friday noon luncheon; his subject was "Designing Academic Libraries." His address was followed by discussion groups which repeated the same topics given in the morning. Charles Stevens, executive director of the National Commission on Libraries and Information Science, was banquet speaker in the evening, bringing delegates up-to-date on the work of the National Commission.

Chartered buses took librarians to the University of Chicago campus on Saturday morning, where they had the opportunity of touring the handsome new Regenstein Library. No one gets into Regenstein without proper identification, as some delegates who arrived by car ahead of the buses discovered! The final registration figures indicated that 469 delegates from nine states and the District of Columbia attended the Evanston conference.

\section{Iowa Hosts \\ A Typical Conference}

Although normally circumscribed by academic libraries from the core states of Ohio, Indiana, Michigan, Illinois, Missouri, Minnesota, Wisconsin, and Iowa, the Midwest Academic Librarians Conference has drawn from various other states at different times, depending upon the geographical location of the conference. Such was the case when the eighteenth MALC met on May 1819, 1973, at Luther College, Decorah, Iowa. Because of its location in the scenic northwestern corner of Iowa, librarians from South Dakota and Nebraska were also included in the ad- 
vance mailing. Oivind M. Hovde, Luther's librarian, was host for the 1973 meetings, and Edmund R. Arnold (Cornell College), chairman of the MALC Steering Committee, shared in the program planning.

Aware that participants would be arriving at various times, depending upon the distance traveled, the Luther library staff provided registration, refreshments, and tours throughout the day on Friday, May 18. At the opening session in the field house, Wisconsin State archivist, F. Gerald Ham, spoke on the subject, "Archivists and Librarians: Imperatives of Collaboration." Following this first meeting, discussion groups relating to the general conference theme, "The Library's Role in the Teaching Process," were conducted. An informal reception, given through the courtesy of Hertzberg New Method Bindery (Des Moines), preceded a Norwegian smorgasbord dinner in the Centennial Union dining room. Dinner speaker was Beverly P. Lynch, executive secretary of the Association of College and Research Libraries, who spoke on "The Organizational Nature of the Academic Library." 4

Group discussions continued on Saturday morning, revolving around the conference theme of the teaching role of the academic library. Topics of the seven discussion groups were: "Teaching the Use of the Library," "Teaching through Reference Services," "Teaching with Non-Book Materials," "Teaching with Local Materials," "Teaching with Realia," "Extending Library Resources," and "The Planning of Preus Library." The final session was held at eleven o'clock, with MALC chairman Edmund Arnold presiding. The Luther College conference, in my opinion, will be remembered as the one which most nearly typifies the image of MALC as conceived by the founders twenty years ago: a small campus, a recently completed building, a friendly and gracious setting, and a stimulating and provocative program that provided opportunity for involvement.

\section{MALC RETURNS TO THE Metropolis}

The University of Wisconsin-Milwaukee was host for the nineteenth MALC conference, May 23-25, 1974, with the theme: "Libraries, Education, Legislation, and National Priorities." According to the advance announcement mailed in March, "the conference schedule includes program meetings, discussion groups, luncheon and dinner sessions, and tours of Milwaukee area libraries and museums." William C. Roselle, director of libraries, served as host, with Edmund Arnold continuing as MALC chairman. Those arriving on Thursday evening, May 23, were treated to an informal "Milwaukee Gemütlichkeit" which lasted into the wee hours of the night. Enclosed with other informational material, a separate housing registration form announced that Spartan campus accommodations were available in the Carl Sandburg Halls of Residence, or off-campus reservations could be had at the Holiday Inn.

Since delegates continued to arrive at various hours throughout Friday morning, registration, complimentary coffee, and tours of the UWM Library were available until the first session started at one o'clock. The keynote address was given by the popular Richard $\mathrm{M}$. Dougherty (who first appeared on a MALC program at Drake University), now librarian, University of California (Berkeley). Following the first session, afternoon tours were scheduled to appeal to all appetites: (1) Milwaukee Zoo and the UWM Library; (2) UWParkside Library (Racine); (3) Milwaukee Public Library and Milwaukee Public Museum; (4) Charles Allis Art Library and Marquette University; (5) the Schlitz Brewery and the Mitchell Botanical Conservatory.

A cocktail reception preceded the eve- 
ning dinner at the Student Union. After dinner speaker was Edward A. Wiegner, senior vice-president/treasurer, Wisconsin Power and Light Company (Madison). Many prominent librarians were involved in the ten discussion groups conducted on Saturday morning. Participants were able to choose two topics, since each discussion was repeated following the mid-morning coffee break. Subjects covered were: government publications, the Upper Midwest Regional Library Group, WILS-MINITEX, approval plans, academic status, ALA standards for college libraries, and three groups dealing with topics related directly to the University of WisconsinMilwaukee's new building. A delightful talk concerning library service to men at sea was given by Harry R. Skallerup, associate librarian, United States Naval Academy, at the closing luncheon on Saturday noon.

No resume of MALC's history would be complete without reference to its international dimension. On several occasions in recent years, having seen announcement of MALC conferences, librarians outside the United States have written to ask if proceedings of the conference program would be available. One such letter came from a university librarian in Selangor, Malaysia; another was received from Calcutta. All such correspondence was acknowledged, indicating the unique nature of the group, and the fact that MALC has never had either the staff or the funds necessary for publishing proceedings. Occasionally foreign librarians attend a MALC conference, such as the ten delegates from Canada who attended the conference at Indiana University in the spring of 1971.

\section{By Way of Conclusion}

Over the past decade the Midwest Academic Librarians Conference has maintained a reputation for stimulating and provocative sessions in spite of the divergent nature of the host institutions, the geographical locale, and the steadily increasing number of participants. It has met on three small college campuses, plus a cluster of three in one community; on two medium-sized university campuses; and at four large university centers. The contagion of success has increased annual attendance from approximately 100 to nearly 500 , and some academic librarians are now concerned that both this increase in size and the selection of larger campuses will dilute the vitality and original purposes that have contributed so much to MALC's uniqueness. Other librarians feel that perhaps it is time to be more flexible and amenable to change.

One key to the success of MALC was recently expressed in a letter received from the librarian of a small, liberal arts college: "Perhaps most memorable ... was that first impression that MALC was a meeting where one got to meet with and talk to people." 5 The fact that it is limited to professionals of a particular type of library, that it is an informal group with no elected offices or dues, that program participants receive no compensation and are expected to pay their own way, and that it is generally restricted to the states surrounding the Great Lakes region, all contribute to the unusual nature of MALC conferences. Another academic librarian commented in a letter: "Hosting a conference like MALC offers the staff of a small library . . . some unique challenges and opportunities-involvement in everything from program planning to menu selection and finding suitable housing." 6

Traditionally, MALC has placed strong emphasis upon discussion, participation, and interaction at its annual conferences. Interestingly, the same topics keep recurring: "Library Cooperation," "Automation," and "The Teaching Role of the Academic Library." If all topics from all of the conferences 
were tallied, it would be evident that scarcely any significant concern of academic librarianship has been overlooked in the program planning of the past twenty years. Perhaps I may be permitted to close with the final sentence which was used in my earlier "history": "Those who have had the professional stimulation and shared in the friendly fellowship as participants of these conferences know to whom the credit should go, and that is perhaps the most sensible conclusion for this informal biography of one of the most viable and rewarding professional groups on the American library scene."7

\section{ReFERENCES}

1. An earlier history of MALC was published in the article by H. Vail Deale, "A Decade with MALC," College \& Research Libraries 25:475-82 (November 1964).

2. Deale, "A Decade with MALC," p.475.

3. Russell S. Dozer to Katharine Stokes, Western Michigan University, May 9, 1961 (MALC archives).

4. This address served as the basis for the ar- ticle, "The Academic Library and its Environment," College \& Research Libraries 35:126-32 (March 1974).

5. Edmund R. Arnold, librarian, Cornell College, to the author, December 27, 1974.

6. Oivind Hovde, librarian, Luther College, to the author, December 19, 1974.

7. Deale, "A Decade with MALC," p.482.

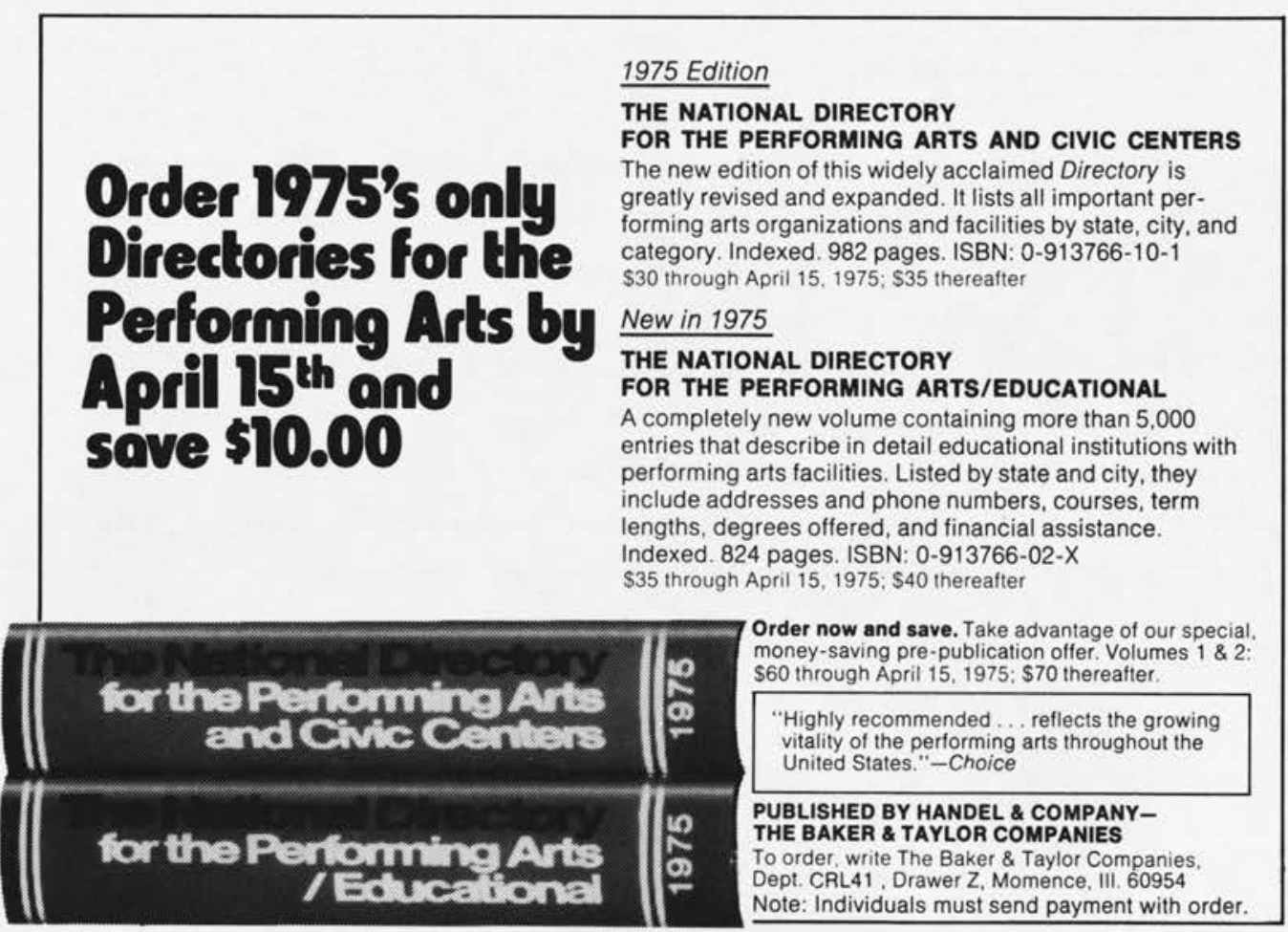




\section{YES,}

\section{We Make Mistakes!}

$\mathbf{E}_{\text {ven though they are rare, we are human at the Book House and we }}$ make mistakes on occasion!

Does it surprise you that we admit to being human? We are human and we treat you like you are human - as friendly, cooperative counsellors and advisors who are prepared to serve you as efficiently and quickly as possible.

$\mathbf{N}_{\text {ow, about those mistakes. If we make them, you will find that we }}$ will correct them with a minimum of problems for you. No computer will keep repeating the same error of title, edition, price or credit for return.

T he human side of this business is what we enjoy - our contacts with you - our efforts to please you are the real joys of this business for everyone of the Book House professionals.

B ook House will deliver any book in print including all university presses, professional and non-profit associations, Government publications, Canadian titles and ALL paperbacks. Why not give Book House a trial order and find out what human, Concerned Service can do for you! Just let us know if you want to receive our occasional newsletter.

ANY QUESTIONS? CALL 517-849-9361 COLLECT!

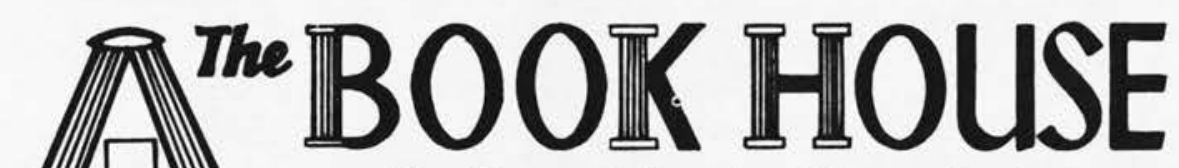

The House of Superior Library Service 208 West Chicago / Jonesville, Mich. 49250 